\title{
Sorption of platinum on immobilized microorganisms for its on-line preconcentration and chemiluminescent determination in water samples
}

\author{
Julita Malejko • Marzena Szygalowicz • \\ Beata Godlewska-Żyłkiewicz • Anatol Kojło
}

Received: 27 July 2011 /Accepted: 7 November 2011 /Published online: 20 November 2011

(C) The Author(s) 2011. This article is published with open access at Springerlink.com

\begin{abstract}
Fungi of the type Aspergillus sp. were immobilized on a cellulosic resin and used as a biosorbent for the on-line preconcentration and separation of $\mathrm{Pt}(\mathrm{IV})$ ions prior to their chemiluminescent determination via flow injection analysis. Biosorption and elution conditions were optimized, and the results compared to biosorbents based on the use of Chlorella vulgaris algae and Saccharomyces cerevisiae yeast in terms of preconcentration and selective retention of $\mathrm{Pt}(\mathrm{IV})$. The immobilized fungi presented here have a high potential for use in platinum biosorption. The procedure exhibits the currently lowest limit of detection $\left(0.02 \mathrm{ng} \mathrm{mL}^{-1}\right.$ of Pt) and very high selectivity. The procedure was applied to the determination of Pt(IV) in river water, road run-off, and wastewater samples.
\end{abstract}

Keywords Biosorption · Platinum · Chemiluminescence . Luminol - Environmental samples · Flow injection analysis

\section{Introduction}

Automotive catalytic converters are a primary source of emission of platinum, palladium and rhodium (PGEplatinum group elements) into the environment. Due to attrition of the catalyst surface during vehicle operation, PGE-containing particles are emitted with exhaust fumes at rates of several hundred $\mathrm{ng} \mathrm{km}^{-1}$ per car. It has been proven that these particles accumulate in airborne and roadside dust, soil and vegetation and are transported to surface

J. Malejko $(\bowtie) \cdot$ M. Szygałowicz • B. Godlewska-Żyłkiewicz • A. Kojło

Institute of Chemistry, University of Bialystok,

Hurtowa 1, 15-399 Białystok, Poland

e-mail: j.malejko@uwb.edu.pl waters via road run-off [1-3]. A number of studies have been undertaken to develop reliable methods for the determination of platinum in environmental matrices. For this purpose, electrothermal atomic absorption spectrometry (ETAAS), inductively coupled plasma atomic emission spectrometry (ICP-AES), inductively coupled plasma mass spectrometry (ICP-MS) and adsorptive stripping voltammetry (AdSV) are mostly applied [4].

Only a few examples of chemiluminescence methods of $\mathrm{Pt}(\mathrm{IV})$ determination have been reported in the literature [5-7]. These methods are characterized by poor precision (RSD $\leq 10 \%$ ), because the measurements were performed in a batch mode. A chemiluminescence flow injection (CLFIA) method of Pt(IV) determination has been developed in our laboratory [8]. It is based on the chemiluminescence reaction of luminol oxidation in aqueous alkaline medium. Luminol is oxidized to yield electronic excited state 3 -aminophthalate, which emits the radiation at $425 \mathrm{~nm}$ on falling to the ground state [9]. Chlorocomplexes of Pt(IV) acting as a catalyst of this reaction can be determined at very low concentration levels (ng $\mathrm{mL}^{-1}$ ) [8]. High sensitivity and precision, and inexpensive instrumentation are the main advantages of this method. However, the accuracy of CL determination of platinum in environmental samples is strongly affected by matrix components (other metals and organic compounds). In order to avoid matrix interferences, application of procedure of analyte separation is necessary. It has been demonstrated that biosorbents are very effective materials for the separation and preconcentration of metal ions in solid phase extraction procedures [10]. Biosorbents are prepared from biologically inactive microorganisms, including algae, fungi, yeast and bacteria [e.g. 11, 12]. In order to obtain particles with good mechanical properties, biomass is immobilized in/on natural or synthetic support. The efficiency of metal 
biosorption by microorganisms mainly depends on the chemical structure of the cell wall. The biomass cell wall is a complex network of various binding sites with different affinities for metal ions [13]. Other important parameters influencing the biosorption process are sample $\mathrm{pH}$, ionic strength and presence of other metal ions competing for functional groups. The mechanism of metal biosorption can be a combination of physical adsorption, ion exchange, complexation and microprecipitation [14]. In our previous studies algae Chlorella vulgaris immobilized on Cellex-T resin support and yeast Saccharomyces cerevisiae immobilized in calcium alginate beads have been applied to the preconcentration and separation of $\mathrm{Pt}(\mathrm{IV})$ before its determination by luminol-based CL method [15, 16]. However, the procedures may be used only for the determination of platinum in simple matrices, such as natural waters. Therefore, our further studies focused on searching more selective biosorbent. Filamentous fungi (Penicillium sp., Aspergillus sp., Rhizopus sp.) are ubiquitous in natural environment and important in a variety of industrial processes. The cell wall of the fungi is a thick, rigid structure composed of complex layers of polysaccharides (80-90\%), proteins, lipids, and polyphosphates. The most common constituent of the wall is chitin, consisting of $\mathrm{N}$-acetylglucosamine residues [13]. Recently fungi Aspergillus $s p$. immobilized in calcium alginate and on Cellex-T resin have been applied to the separation and preconcentration of $\mathrm{Pt}$ and Pd before their determination in environmental samples by ETAAS [17].

We describe here a method using Aspergillus sp. immobilized on a cellulosic resin as a biosorbent for the separation of $\mathrm{Pt}(\mathrm{IV})$ ions prior to their chemiluminescent determination via flow injection analysis. The CL method is based on monitoring the light intensity generated in the reaction of luminol oxidation catalysed by Pt(IV) ions. Our paper also covers the comparison of immobilized fungi with biosorbents studied earlier, namely algae $C$. vulgaris immobilized on Cellex-T resin [15] and yeast $S$. cerevisiae immobilized in calcium alginate beads [16] in terms of their biosorption performance and applicability for platinum separation from environmental samples prior to its determination by CL method.

\section{Experimental}

Reagents and materials

A standard solution of platinum as hexachloroplatinic(IV) acid (30\%) (POCh, Poland, www.poch.com.pl) was used. Stock solution of $\mathrm{Pt}(\mathrm{IV})\left(1,000 \mu \mathrm{g} \mathrm{g}^{-1}\right)$ was prepared in $1 \mathrm{~mol} \mathrm{~L}^{-1}$ hydrochloric acid (Trace Select, Fluka, France, www.sigmaaldrich.com). Working standard solutions were prepared daily by diluting the stock solution with $\mathrm{HCl}$ solution of $\mathrm{pH} 1.0$.

Luminol ( $\geq 98,0 \%$, Fluka, Russia, www.sigmaaldrich.com) stock solution $\left(2.5 \cdot 10^{-2} \mathrm{~mol} \mathrm{~L}^{-1}\right)$ was prepared by dissolving an appropriate amount of the compound in $1 \mathrm{~mol} \mathrm{~L}^{-1} \mathrm{NaOH}$ solution and stored in a refrigerator (at $4{ }^{\circ} \mathrm{C}$ ) for $24 \mathrm{~h}$ prior to use, to ensure the stability of the measurements. Working solution $\left(5.0 \cdot 10^{-3} \mathrm{~mol} \mathrm{~L}^{-1}\right.$ luminol in $\left.0.2 \mathrm{~mol} \mathrm{~L}^{-1} \mathrm{NaOH}\right)$ was prepared before use by dilution of the stock solution with Milli-Q water. The analytical grade reagents: sodium hydroxide (POCh, Poland, www.poch.com.pl) and sodium chloride (Sigma-Aldrich, Denmark, www.sigmaaldrich.com) were also used.

A growth medium Czapek Dox Agar (Fluka, Switzerland, www.sigmaaldrich.com) containing sucrose $\left(30 \mathrm{gL}^{-1}\right)$, agar $\left(15 \mathrm{gL}^{-1}\right), \mathrm{NaNO}_{3}\left(3 \mathrm{gL}^{-1}\right), \mathrm{K}_{2} \mathrm{HPO}_{4}\left(1 \mathrm{gL}^{-1}\right), \mathrm{KCl}\left(0.5 \mathrm{gL}^{-1}\right)$, $\mathrm{MgSO}_{4} \cdot 7 \mathrm{H}_{2} \mathrm{O}\left(0.5 \mathrm{gL}^{-1}\right), \mathrm{FeSO}_{4} \cdot 7 \mathrm{H}_{2} \mathrm{O}\left(0.01 \mathrm{gL}^{-1}\right)$ was used for the cultivation of fungi Aspergillus $s p$.

Yeast extract (Fluka, Switzerland, www.sigmaaldrich. com) - an extract of autolyzed yeast cells (a mixture of amino acids, peptides, water soluble vitamins and carbohydrates) was used as additive for a culture medium.

Cellex-T resin (Bio-Rad Laboratories, USA, www.bio-rad. com), cellulose anion-exchanger (triethylaminocellulose) was used as a support material for the immobilization of fungi Aspergillus $s p$.

Reversed-phase $\mathrm{C}_{18}$ bonded silica gel (LiChroprep RP-18, 25-40 $\mu \mathrm{m}$ particle size, Merck, Germany, www.merckchemicals.com) was used.

The environmental samples analyzed in this study were: water from the Biała river (Białystok, Poland), wastewater collected from municipal sewage treatment plant in Białystok and road run-off taken from the retention reservoir at the ring road of Białystok.

\section{Instrumentation}

A CL-FIA manifold used in this work was the same as in our previous study [16], except that the column was filled with fungi Aspergillus sp. immobilized on Cellex-T. Briefly, the flow injection manifold was composed of two peristaltic pumps (Gilson Minipuls, France, www.gilson.com); a rotary injection valve (Model 5021 Rheodyne, USA, www.chromtech.com); laboratory made glassy column (30 mm length, $6 \mathrm{~mm}$ i.d.) packed with the biosorbent and installed in the injection valve; flow luminometer (KSP, Poland).

A PU 9100X (Philips Scientific, UK) atomic absorption spectrometer equipped with PU 9390X electrothermal atomizer, FS-90 autosampler, deuterium background correction system and platinum hollow cathode lamp (Photron, Australia, www.photron.com.au) was used. The measuring conditions for Pt determination were described elsewhere [18]. 
For pH measurements, pHmeter CP-315M (Elmetron, Poland, www.elmetron.com.pl) was used.

A solid phase extraction unit Spe-12G (J.T. Baker, Germany, www.witko.com.pl) equipped with a glassy column filled with LiChroprep RP-18 was used to remove the interfering organic matrix from real samples.

Procedures of cultivation and immobilization of Aspergillus $s p$

The medium used for the cultivation of fungi Aspergillus sp. was prepared by dissolving $7.5 \mathrm{~g}$ of Czapek Dox Agar and $0.58 \mathrm{~g}$ of yeast extract in $150 \mathrm{~mL}$ of warm Milli-Q water. The growth medium was sterilized by autoclaving at $121{ }^{\circ} \mathrm{C}$ and poured onto Petri plates. Aspergillus sp. was inoculated on solidified medium and incubated at $30{ }^{\circ} \mathrm{C}$ for 3 days. Then the biomass was separated from the growth medium, washed with $0.1 \mathrm{~mol} \mathrm{~L}^{-1} \mathrm{HCl}$ and Milli-Q water and next was immobilized on Cellex-T support. The biomass was added to the resin (mass ratio 1:3), wetted with Milli-Q water, thoroughly mixed and then dried at $60{ }^{\circ} \mathrm{C}$. The procedure (wetting, mixing and drying) was repeated twice in order to maximize the contact between the biomass and support surface.

Procedure of platinum preconcentration on biosorbent and its CL determination

Before analysis, a column filled with immobilized fungi $(0.15 \mathrm{~g})$ was preconditioned by passing $0.25 \mathrm{~mol} \mathrm{~L}^{-1} \mathrm{HCl}$ solution $(5 \mathrm{~mL})$ and next Milli-Q water $(4 \mathrm{~mL})$ at a flow rate of $2.0 \mathrm{~mL} \mathrm{~min}{ }^{-1}$. The $\mathrm{Pt}(\mathrm{IV})$ standard or sample solution $(10 \mathrm{~mL})$ of $\mathrm{pH} 1.0$ was loaded onto the column at a flow rate of $2.0 \mathrm{~mL} \mathrm{~min}^{-1}$ for the analyte retention and the effluent was directed to wastes. After that, the column was washed with $4 \mathrm{~mL}$ of Milli-Q water. The next stage in the procedure involved the elution of the bound platinum from the biosorbent. It was accomplished by passing $5.0 \mathrm{~mol} \mathrm{~L}^{-1}$ $\mathrm{NaCl}$ solution through the column at a flow rate of $2.2 \mathrm{~mL} \mathrm{~min}{ }^{-1}$. The eluent was merged with the reagent solution $\left(5.0 \cdot 10^{-3} \mathrm{~mol} \mathrm{~L}^{-1}\right.$ luminol in $\left.0.2 \mathrm{~mol} \mathrm{~L}^{-1} \mathrm{NaOH}\right)$ pumped at a flow rate of $2.2 \mathrm{~mL} \mathrm{~min}{ }^{-1}$ and the resulting solution was directed to the flow cell. Increase in the chemiluminescence intensity relative to the baseline, corresponding to concentration of $\mathrm{Pt}(\mathrm{IV})$ ions, was measured with the CL detector. The average lifetime of the column was around 50 analytical cycles.

Pretreatment of environmental samples

Samples of river water and road run-off were spiked with $\mathrm{Pt}$ $\left(0.1 ; 0.25 ; 1.0 \mathrm{ng} \mathrm{mL}^{-1}\right)$. After $2 \mathrm{~h}$ equilibration, samples were filtered through Iso-Disc Filters PTFE $(25 \mathrm{~mm} \times$
$0.45 \mu \mathrm{m}$, Supelco, USA, www.sigmaaldrich.com) and adjusted to the required $\mathrm{pH}$ with hydrochloric acid.

Samples of wastewater were filtered through cellulose filters with soft and wide pores (Filtrak 388, Germany), acidified to $\mathrm{pH} 1$ with $\mathrm{HCl}$ and stored in a refrigerator. Before analysis samples were spiked with $\mathrm{Pt}(\mathrm{IV})$ standard $\left(0.25 ; 1.0 \mathrm{ng} \mathrm{mL}^{-1}\right)$.

The interfering compounds present in environmental samples were retained on reversed phase $\mathrm{C}_{18}$ column packed with $500 \mathrm{mg}$ of LiChroprep RP-18. The sorbent was conditioned by passing $5 \mathrm{~mL}$ of methanol and $5 \mathrm{~mL}$ of $0.01 \mathrm{~mol} \mathrm{~L}^{-1}$ hydrochloric acid. The sample solution was passed through the column at a flow rate of $1.0 \mathrm{~mL} \mathrm{~min}^{-1}$ and the effluent was collected and loaded onto the column filled with the biosorbent.

\section{Results and discussion}

Optimization of platinum preconcentration conditions on Aspergillus sp. immobilized on cellex-T

In order to determine the suitability of the biosorbent for the preconcentration of $\mathrm{Pt}(\mathrm{IV})$ ions, the following parameters were optimized: the sample $\mathrm{pH}$ and the rate of passing the sample solution through the column. The influence of the $\mathrm{pH}$ on biosorption efficiency of platinum was studied in the range from 0.25 to 4.0 . The $\mathrm{Pt}(\mathrm{IV})$ solutions were adjusted to the required $\mathrm{pH}$ with hydrochloric acid and loaded onto the column packed with immobilized fungi. The collected effluents were analyzed for the remaining metal by ETAAS. It was observed that efficiency of platinum biosorption was almost constant (97.7-99.2\%) in the studied $\mathrm{pH}$ range. In further experiments solutions of $\mathrm{Pt}(\mathrm{IV})$ were adjusted with $\mathrm{HCl}$ to $\mathrm{pH}$ 1.0. In such solutions platinum is present in the form of anionic chlorocomplexes (mainly $\mathrm{PtCl}_{6}{ }^{2-}$ and $\left.\mathrm{PtCl}_{5}\left(\mathrm{H}_{2} \mathrm{O}\right)^{-}\right)$[19] and can interact with the protonated active sites of the cell wall of investigated microorganism. Literature survey shows that the optimal $\mathrm{pH}$ for the retention of other metal ions such as $\mathrm{Cu}(\mathrm{II}), \mathrm{Pb}(\mathrm{II}), \mathrm{Zn}$ (II), $\mathrm{Fe}(\mathrm{III}), \mathrm{Ni}(\mathrm{II}), \mathrm{Co}(\mathrm{II})$ and $\mathrm{Cd}(\mathrm{II})$ on fungi Aspergillus (A. fumigatus immobilized on Diaion HP-2MG resin [20], $A$. niger immobilized on silica gel [21], A. niger immobilized on sepiolite [22]) is in the range 6-8. Hence, strongly acidic medium ( $\mathrm{pH}$ 1.0) should provide a good selectivity of platinum biosorption process. In the case of algae $C$. vulgaris immobilized on Cellex-T resin platinum was the most efficiently retained in the $\mathrm{pH}$ range from 1.5 to 1.8 [23]. For yeast $S$. cerevisiae immobilized in calcium alginate the highest biosorption efficiency was observed in a wide range of $\mathrm{pH}$ from 1.5 to 6.5 [16]. At the optimal $\mathrm{pH}$, immobilized fungi demonstrated higher biosorption efficiency of $\mathrm{Pt}(\mathrm{IV})$ chlorocomplexes $(99.2 \%)$ compared to 
immobilized algae (95.2\%) [23] and yeast (90.3\%) [16]. Variations in biosorption efficiency can be attributed to differences in composition and structure of cell walls of tested microorganisms and in consequence to differences in biosorption mechanisms. Also the effect of the type of support used for the immobilization of biomass should not be neglected.

Subsequent studies showed that the flow rate of $\mathrm{Pt}$ (IV) solutions (in the range from 0.6 to $2.2 \mathrm{~mL} \mathrm{~min}^{-1}$ ) practically does not affect the efficiency of biosorption (98.1-99.2\%). In order to shorten the analysis time, the flow rate of $2.0 \mathrm{~mL} \mathrm{~min}{ }^{-1}$ was chosen for further experiments. The same flow rate was used in the case of algae column [15], but much lower $\left(0.5 \mathrm{~mL} \mathrm{~min}^{-1}\right)$ in the case of yeast column [16]. This indicates that immobilized fungi and algae are characterized by faster kinetics of biosorption than immobilized yeast.

Our previous study [15] demonstrated that quantitative elution of Pt(IV) from algae C. vulgaris immobilized on Cellex-T resin can be obtained by using sodium chloride solution. Additional advantage of this solution is that it shows a positive influence on analytical signal of Pt(IV) measured by luminol-based CL method. The present study revealed that sodium chloride solution can also be applied for desorbing of platinum from fungi Aspergillus $s p$. immobilized on Cellex-T. Therefore, $\mathrm{NaCl}$ solution was used as an eluent/carrier stream in the CL-FIA manifold equipped with fungi column and the effect of its concentration (in the range $3.0-5.5 \mathrm{~mol} \mathrm{~L}^{-1}$ ) on platinum signals was investigated (Fig. 1a). A three-fold increase in CL signals of platinum was observed when the $\mathrm{NaCl}$ concentration was raised from 3.0 to $5.0 \mathrm{~mol} \mathrm{~L}^{-1}$. To ensure maximum sensitivity of measurements, the solution of $5.0 \mathrm{~mol} \mathrm{~L}^{-1} \mathrm{NaCl}$ was selected for further experiments. In our previous studies $[15,16]$ the highest $\mathrm{CL}$ signals of $\mathrm{Pt}$ (IV) were obtained for lower concentration of sodium chloride $-3.0 \mathrm{~mol} \mathrm{~L}^{-1}$.

As can be seen from Fig. 1b, analytical signals of platinum increased with increasing the flow rate of eluent and luminol streams in the range $0.9-2.5 \mathrm{~mL} \mathrm{~min}^{-1}$. The flow rate equal to $2.2 \mathrm{~mL} \mathrm{~min}^{-1}$ was chosen for subsequent experiments. At higher values considerable resistance in the flow of eluent through the column was observed. The same flow rate was used in the case of algae [15] and yeast column [16]. The optimal conditions of platinum extraction procedures on tested biosorbents are given in Table 1.

The recovery of platinum from immobilized fungi obtained at optimal values of studied parameters was $92.0 \pm 8.8 \%(n=3)$. It was slightly lower than that obtained for the preconcentration procedure of platinum on algae column (98.5\%) [15], but greater than that obtained in the case of yeast column $(83.0 \%)$ [16]. The complete recoveries of Pt from fungi and algae achieved with concentrated $\mathrm{NaCl}$ solution indicate that

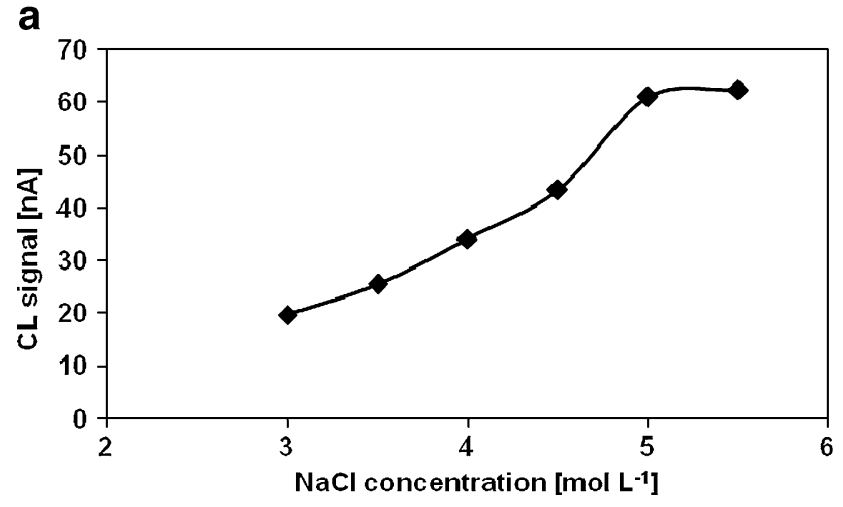

b

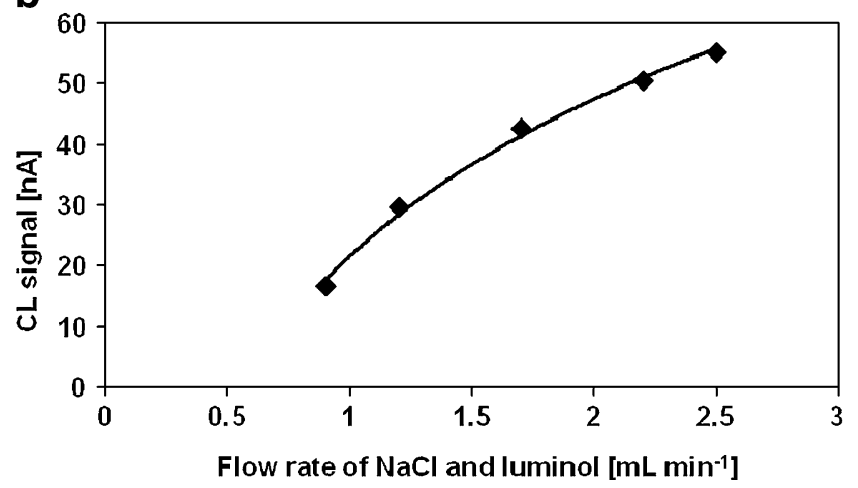

Fig. 1 Effect of elution conditions on CL signal of Pt(IV) $\left(1 \mathrm{ng} \mathrm{mL}^{-1}\right)$ : a $\mathrm{NaCl}$ concentration $\left(\mathrm{C}_{\mathrm{Lum}}=5.0 \cdot 10^{-3} \mathrm{~mol} \mathrm{~L}^{-1}, \mathrm{C}_{\mathrm{NaOH}}=0.2 \mathrm{~mol} \mathrm{~L}^{-1}\right.$, flow rate $\left.=2.2 \mathrm{~mL} \mathrm{~min}^{-1}\right)$; $\mathbf{b}$ flow rate of eluent and luminol streams $\left(\mathrm{C}_{\mathrm{NaCl}}=\right.$ $5.0 \mathrm{~mol} \mathrm{~L}^{-1}, \mathrm{C}_{\mathrm{Lum}}=5.0 \cdot 10^{-3} \mathrm{~mol} \mathrm{~L}^{-1}, \mathrm{C}_{\mathrm{NaOH}}=0.2 \mathrm{~mol} \mathrm{~L}^{-1}$ )

electrostatic interactions are responsible for binding of $\mathrm{Pt}$ (IV) chlorocomplexes to the biosorbents. The lower recovery from immobilized $S$. cerevisiae suggests that in this case, electrostatic forces are not the only kind of interactions involved in the metal binding. It has been reported by Mack et al. [24] that biosorption of Pt(IV) chlorocomplexes by immobilized yeast from solutions of $\mathrm{pH} 1.5$ involves chemical sorption mechanism such as covalent bonding.

The same concentrations of luminol and $\mathrm{NaOH}$ $\left(5.0 \cdot 10^{-3} \mathrm{~mol} \mathrm{~L}^{-1}\right.$ luminol in $\left.0.2 \mathrm{~mol} \mathrm{~L}^{-1} \mathrm{NaOH}\right)$ as in the earlier studies $[15,16]$ were applied.

\section{Effect of the interfering ions}

The interfering effect of other metal ions commonly present in environmental samples on the determination of $\mathrm{Pt}(\mathrm{IV})$ by the CL-FIA method was studied. For this purpose, solutions of $\mathrm{Pt}(\mathrm{IV})$ ions $\left(1.0 \mathrm{ng} \mathrm{mL} \mathrm{m}^{-1}\right)$ spiked with different concentrations of matrix ions (as listed in Table 2) were subjected to the separation procedure on Aspergillus sp. immobilized on Cellex-T. For comparison, the influence of metal ions on luminol-based CL determination of platinum after its separation on algae and yeast column was also 
Table 1 Optimal conditions of extraction procedures of Pt(IV) on biosorbents [this work, 15, 16]

\begin{tabular}{llll}
\hline & \multicolumn{2}{l}{ Type of biosorbent } & \\
\cline { 2 - 4 } & Fungi Aspergillus/Cellex-T & Algae C. vulgaris/Cellex-T & Yeast S. cerevisiae/alginate \\
\hline Mass of biosorbent & $150 \mathrm{mg}$ & $150 \mathrm{mg}$ & $600 \mathrm{mg}$ \\
Sample pH & 1.0 & 1.8 & 1.8 \\
Sample flow rate & $2.0 \mathrm{~mL} \mathrm{~min}^{-1}$ & $2.0 \mathrm{~mL} \mathrm{~min}^{-1}$ & $0.5 \mathrm{~mL} \mathrm{~min}^{-1}$ \\
Type of eluent & $5.0 \mathrm{~mol} \mathrm{~L}^{-1} \mathrm{NaCl}$ & $3.0 \mathrm{~mol} \mathrm{~L}^{-1} \mathrm{NaCl}$ & $3.0 \mathrm{~mol} \mathrm{~L}^{-1} \mathrm{NaCl}$ \\
Eluent flow rate & $2.2 \mathrm{~mL} \mathrm{~min}^{-1}$ & $2.2 \mathrm{~mL} \mathrm{~min}^{-1}$ & $2.0 \mathrm{~mL} \mathrm{~min}^{-1}$ \\
\hline
\end{tabular}

presented. As can be seen from Table 2, among the tested biosorbents the immobilized fungi showed the greatest ability to the selective retention of $\mathrm{Pt}(\mathrm{IV})$ in the presence of other metal ions. The acceptable excesses of foreign ions to analyte were the highest (in the range 50-80 000-fold), except for $\mathrm{Cr}(\mathrm{VI})$ and $\mathrm{Cu}(\mathrm{II})$. It is worth noting that the studied biosorbent allows the efficient separation of $\mathrm{Pt}(\mathrm{IV})$ from other ions belonging to PGE, such as Pd(II), Rh(III) and $\mathrm{Pt}(\mathrm{II})$.

\section{Analytical characteristic}

The analytical characteristic of the CL method of Pt(IV) determination after on-line analyte preconcentration on fungi Aspergillus $s p$. immobilized on Cellex-T is presented in Table 3. The analytical parameters obtained in the flow systems with algae and yeast column are showed for comparison. The method is characterized by the lowest limit of detection (expressed as the concentration of the analyte equal to 3.3-fold standard deviation of the intercept or residual standard deviation divided by the slope of the calibration graph, $\mathrm{LOD}=0.02 \mathrm{ng} \mathrm{mL}^{-1} \mathrm{Pt}$ ) and the best sensitivity (the largest slope of the calibration graph). After the biosorption step on immobilized fungi, the sensitivity of CL measurements increased 2-fold and the limit of detection of $\mathrm{Pt}(\mathrm{IV})$ decreased 5-fold compared to the direct measurements (without separation step LOD $=0.1 \mathrm{ng} \mathrm{mL}^{-1}$ $\mathrm{Pt})$. The LOD of the CL method is significantly lower than that obtained by ICP-AES after preconcentration of Pt(IV) on activated carbon modified with ethyl-3-(2-aminoethylamino)-2-chlorobut-2-enoate $\left(9 \mathrm{ng} \mathrm{mL}^{-1}\right)$ [25] and activated carbon modified with 2,6-diaminopyridine $\left(0.29 \mathrm{ng} \mathrm{mL}^{-1}\right)$ [26]. The obtained LOD is comparable with that obtained by ICP-MS after solid-phase extraction of analyte complexes on modified silica gel Separon SGX C18 $\left(0.05 \mathrm{ng} \mathrm{mL}^{-1} \mathrm{Pt}\right)$ [27] and anion-exchange sorbent Dowex AG1-X8 (0.15 $\left.\mathrm{ng} \mathrm{g}^{-1}\right)$ [28] and the same as LOD of ETAAS method with biosorption of platinum on Aspergillus fungi [17]. The calibration graph obtained for standard solutions of $\mathrm{Pt}(\mathrm{IV})$ was linear in the concentration range $0.05-2 \mathrm{ng} \mathrm{mL}^{-1}$. The precision of the method, expressed as the relative standard deviation (RSD) of 12 subsequent
Table 2 Acceptable excess of interfering ions to analyte in determination of $\mathrm{Pt}(\mathrm{IV})$ by the CL-FIA methods with separation step on biosorbents (relative error of determination \pm $5 \%$ ) [this work, 15, 16]

\begin{tabular}{llll}
\hline Interfering ion & \multicolumn{2}{l}{ Acceptable concentration ratio of interferent to analyte } \\
\cline { 2 - 4 } & $\begin{array}{l}\text { Fungi Aspergillus/Cellex-T } \\
\left(1 \mathrm{ng} \mathrm{mL}^{-1} \mathrm{Pt}(\mathrm{IV})\right)\end{array}$ & $\begin{array}{l}\text { Algae } C \text {. vulgaris/Cellex-T } \\
\left(2 \mathrm{ng} \mathrm{mL}^{-1} \mathrm{Pt}(\mathrm{IV})\right)\end{array}$ & $\begin{array}{l}\text { Yeast } S \text {. cerevisiae/alginate } \\
\left(10 \mathrm{ng} \mathrm{m}^{-1} \mathrm{Pt}(\mathrm{IV})\right)\end{array}$ \\
\hline $\mathrm{Al}(\mathrm{III})$ & 80000 & 50000 & - \\
$\mathrm{Pb}(\mathrm{II})$ & 60000 & 25000 & - \\
$\mathrm{Zn}(\mathrm{II})$ & 50000 & 25000 & 100 \\
$\mathrm{Ni}(\mathrm{II})$ & 15000 & 15000 & 100 \\
$\mathrm{Fe}(\mathrm{III})$ & 5,000 & 2,500 & 100 \\
$\mathrm{Mn}(\mathrm{II})$ & 500 & - & - \\
$\mathrm{Cr}(\mathrm{III})$ & 400 & 250 & - \\
$\mathrm{Pd}(\mathrm{II})$ & 200 & 125 & 100 \\
$\mathrm{Rh}(\mathrm{III})$ & 100 & - & - \\
$\mathrm{Pt}(\mathrm{II})$ & 100 & - & - \\
$\mathrm{Cu}(\mathrm{II})$ & 50 & 2,500 & 500 \\
$\mathrm{Co}(\mathrm{II})$ & 50 & 25 & 7.5 \\
$\mathrm{Cr}(\mathrm{VI})$ & 10 & 500 & - \\
\hline
\end{tabular}


Table 3 Analytical characteristic of the CL-FIA methods of determination of Pt(IV) after its preconcentration/separation on biosorbents [this work, 15, 16]

\begin{tabular}{|c|c|c|c|}
\hline & \multicolumn{3}{|l|}{ Type of biosorbent } \\
\hline & Fungi Aspergillus/Cellex-T & Algae $C$. vulgaris/Cellex-T & Yeast $S$. cerevisiae/alginate \\
\hline Determination range $\left[\mathrm{ng} \mathrm{mL}^{-1}\right]$ & $0.05-2$ & $0.1-2.5$ & $1-30$ \\
\hline Slope of the calibration graph \pm S.D. & $41.6 \pm 2.9(n=4)$ & $15.55 \pm 0.44(n=5)$ & $2.61 \pm 0.25(n=4)$ \\
\hline Limit of detection $\left[\mathrm{ng} \mathrm{mL}^{-1}\right]$ & 0.02 & 0.06 & 0.15 \\
\hline Preconcentration factor & 2 & 5 & - \\
\hline $\begin{array}{l}\text { Precision as RSD [\%] } 0.25 \mathrm{ng} \mathrm{mL}^{-1} \\
\mathrm{Pt}(\mathrm{IV}) * 2 \mathrm{ng} \mathrm{mL} L^{-1} \mathrm{Pt}(\mathrm{IV})\end{array}$ & $2.6(n=12)$ & $1.5^{*}(n=10)$ & $3.7^{*}(n=6)$ \\
\hline Sample frequency $\left[\mathrm{h}^{-1}\right]$ & 4 & 5 & 2 \\
\hline
\end{tabular}

measurements of $0.25 \mathrm{ng} \mathrm{mL} \mathrm{m}^{-1}$ concentration of $\mathrm{Pt}(\mathrm{IV})$, was equal to $2.6 \%$.

Application of biosorbent for the separation of platinum from environmental samples

The samples of river water were spiked with $\mathrm{Pt}(\mathrm{IV})$ and analyzed by the CL-FIA method. The approach applied for the removal of organic matrix, which interfere with luminol-based CL determination of platinum, was the same as described previously [16]: samples were passed through a column packed with LiChroprep RP-18 sorbent. The recoveries of $\mathrm{Pt}$ determined by the modified procedure, including sample pre-cleaning step on $\mathrm{C}_{18}$ column followed by biosorption of the analyte on fungi column, are shown in Table 4. Selectivity of the procedure ensures effective separation of interfering matrix and accurate CL determination of Pt(IV) in complex samples, such as road run-off waters and municipal wastewater. This confirms the higher selectivity of platinum biosorption process on fungi Aspergillus $s p$. compared to algae and yeast. The previous studies $[15,16]$ showed that the extraction procedures using algae and yeast column can be applied only for the separation of $\mathrm{Pt}$ (IV) from simple matrices, such as river waters.

\section{Conclusions}

A procedure for the preconcentration and separation of $\mathrm{Pt}(\mathrm{IV})$ ions on fungi Aspergillus sp. immobilized on Cellex-T resin prior to their luminol-based CL determination has been developed. Under the optimal conditions of biosorption and elution steps quantitative recovery of platinum was achieved. After the extraction procedure, the sensitivity of $\mathrm{CL}$ measurements increased 2-fold and the limit of detection of $\mathrm{Pt}(\mathrm{IV})$ decreased 5-fold compared to the direct measurements. For that reason, the method may be applied to the determination of trace amounts of Pt(IV) ions. Due to high selectivity of the used biosorbent, ions of transition metals present in environmental samples, such as river water, road run-off and municipal wastewater, do not interfere with the $\mathrm{CL}$ determination of $\mathrm{Pt}(\mathrm{IV})$ ions. The dissolved organic matter affecting the chemiluminescence of luminol was removed from the samples by means of $\mathrm{C}_{18}$ column. The biosorption performance of the immobilized fungi was compared with that of the biosorbents studied earlier: algae C. vulgaris immobilized on Cellex-T resin [15] and yeast $S$. cerevisiae immobilized in calcium alginate beads [16]. Among the three biomaterials tested, the immobilized fungi proved to be the best biosorbent for Pt(IV), as they exhibit the highest selectivity and, unlike the other two biosorbents, can be used to separate platinum from complex matrix of wastewater samples.

Immobilized microorganisms are useful solid sorbents for effective separation/preconcentration of trace metals before their chemiluminescent determination. With proper choice of the microorganism and immobilization technique, biosorbents could satisfactory replace other solid phase materials. The main advantages of using biosorbents are the effectiveness in removing of metal ions at very low concentration levels, the availability of microorganisms, ease of production, and low cost.

Table 4 Recovery of Pt(IV) from real samples after removal of organic matrix on RP-18 column and analyte preconcentration on fungi Aspergillus sp. immobilized on Cellex-T

\begin{tabular}{llcl}
\hline Sample & \multicolumn{2}{l}{$\begin{array}{l}\text { Concentration of } \\
\text { Pt(IV) }\left[\mathrm{ng} \mathrm{mL}^{-1}\right]\end{array}$} & $\begin{array}{l}\text { Recovery of Pt } \pm \text { S.D. } \\
{[\%](n=4)}\end{array}$ \\
\cline { 2 - 3 } & Added & Found \pm S.D. $(n=4)$ & \\
\hline Biała River & 0.10 & $0.10 \pm 0.01$ & $100 \pm 9$ \\
& 0.25 & $0.27 \pm 0.01$ & $108 \pm 3$ \\
& 1.0 & $0.96 \pm 0.04$ & $96 \pm 4$ \\
Road run-off & 0.25 & $0.27 \pm 0.01$ & $108 \pm 4$ \\
& 1.0 & $1.05 \pm 0.07$ & $105 \pm 7$ \\
Wastewater & 0.25 & $0.26 \pm 0.02$ & $104 \pm 8$ \\
& 1.0 & $1.06 \pm 0.03$ & $106 \pm 3$ \\
\hline
\end{tabular}


Open Access This article is distributed under the terms of the Creative Commons Attribution Noncommercial License which permits any noncommercial use, distribution, and reproduction in any medium, provided the original author(s) and source are credited.

\section{References}

1. Zereini F, Alt F (2000) Anthropogenic platinum-group element emissions. Their impact on man and environment. Springer, Berlin

2. Zereini F, Alt F (2006) Palladium emissions in the environment. Analytical methods, environmental assessment and health effects. Springer, Berlin

3. Ek KH, Morrison GM, Rauch S (2004) Environmental routes for platinum group elements to biological materials - a review. Sci Total Environ 334-335:21-38

4. Bencs L, Ravindra K, van Grieken R (2003) Methods for the determination of platinum group elements originating from the abrasion of automotive catalytic converters. Spectrochim Acta Part B 58:1723-1755

5. Lukovskaya NM, Terletskaya AV, Kushchevskaya NP (1978) Catalytic action of iridium and platinum in chemiluminescence reaction between luminol and hydrogen peroxide. Zh Anal Khim 33:750-753

6. Rigin VI, Bakhmurow AS, Blokhin AI (1975) Kinetic chemiluminescence determination of ultrasmall amounts of platinum. $\mathrm{Zh}$ Anal Khim 30:2413-2417

7. Zaporozhets OA, Pogasii LB, Sukhan VV (1993) Chemiluminescence of 4-diethylaminophthalhydrazide in presence of platinum compounds. Zh Anal Khim 48:75-80

8. Malejko J, Milewska R, Leśniewska B, Godlewska-Żyłkiewicz B, Kojło A (2007) On the effect of hydrogen peroxide on the flowinjection determination of platinum based on luminol chemiluminescent reaction. Anal Lett 40:961-973

9. Barnett NW, Francis PS (2005) Chemiluminescence. In: Worsfold P, Townshend A, Poole C (eds) Encyclopedia of analytical science, 2nd edn. Elsevier, Oxford, pp 506-521

10. Godlewska-Żyłkiewicz B (2006) Microorganisms in inorganic chemical analysis. Anal Bioanal Chem 384:114-123

11. Bakircioglu D, Ucar G, Bakircioglu Kurtulus Y (2011) Coliform bacteria immobilized on titanium dioxide nanoparticles as a biosorbent for trace lead preconcentration followed by atomic absorption spectrometric determination. Microchim Acta 174:367-374

12. Özdemir S, Gul-Guven R, Kilinc E, Dogru M, Erdogan S (2010) Preconcentration of cadmium and nickel using the bioadsorbent Geobacillus thermoleovorans subsp. stromboliensis immobilized on Amberlite XAD-4. Microchim Acta 169:79-85

13. Wang J, Chen C (2009) Biosorbents for heavy metals removal and their future. Biotechnol Adv 27:195-226

14. Park D, Yun YS, Park JM (2010) The past, present and future trends of biosorption. Biotechnol Bioproc Eng 15:86-102

15. Godlewska-Żyłkiewicz B, Malejko J, Hałaburda P, Leśniewska B, Kojło A (2007) Separation of matrix by means of biosorption for flow-injection chemiluminescent determination of trace amounts of Pt(IV) in natural waters. Microchem J 85:314-320
16. Godlewska-Żyłkiewicz B, Malejko J, Leśniewska B, Kojło A (2008) Assessment of immobilized yeast for the separation and determination of platinum in environmental samples by flowinjection chemiluminescence and electrothermal atomic absorption spectrometry. Microchim Acta 163:327-334

17. Woińska S, Godlewska-Żyłkiewicz B (2011) Determination of platinum and palladium in road dust after their separation on immobilized fungus by electrothermal atomic absorption spectrometry. Spectrochim Acta Part B 66:522-528

18. Godlewska-Żyłkiewicz B (2003) Biosorption of platinum and palladium for their separation/preconcentration prior to graphite furnace atomic absorption spectrometric determination. Spectrochim Acta Part B 58:1531-1540

19. Spieker WA, Liu J, Miller JT, Kropf AJ, Regalbuto JR (2002) An EXAFS study of the co-ordination chemistry of hydrogen hexachloroplatinate(IV). 1. Speciation in aqueous solution. Appl Catal A: Gen 232:219-235

20. Soylak M, Tuzen M, Mendil D, Turkekul I (2006) Biosorption of heavy metals on Aspergillus fumigatus immobilized Diaion HP$2 \mathrm{MG}$ resin for their atomic absorption spectrometric determinations. Talanta 70:1129-1135

21. Baytak S, Koçyiğit A, Türker AR (2007) Determination of lead, iron and nickel in water and vegetable samples after preconcentration with Aspergillus niger loaded on silica gel. Clean-Soil, Air, Water 35:607-611

22. Bağ H, Türker AR, Lale M (1999) Determination of trace metals in geological samples by atomic absorption spectrophotometry after preconcentration by Aspergillus niger immobilized on sepiolite. Anal Sci 15:1251-1256

23. Dziwulska U, Bajguz A, Godlewska-Żyłkiewicz B (2004) The use of algae Chlorella vulgaris immobilized on Cellex-T support for separation/preconcentration of trace amounts of platinum and palladium before GFAAS determination. Anal Lett 37:2189-2203

24. Mack CL, Wilhelmi B, Duncan JR, Burgess JE (2008) A kinetic study of the recovery of platinum ions from an artificial aqueous solution by immobilized Saccharomyces cerevisiae biomass. Miner Eng 21:31-37

25. Tu Z, Lu S, Chang X, Li Z, Hu Z, Zhang L, Tian H (2011) Selective solid-phase extraction and separation of trace gold, palladium and platinum using activated carbon modified with ethyl-3-(2-aminoethylamino)-2-chlorobut-2-enoate. Microchim Acta 173:231-239

26. Li D, Chang X, Hu Z, Wang Q, Tu Z, Li R (2011) Selective solidphase extraction of trace $\mathrm{Au}(\mathrm{III}), \mathrm{Pd}(\mathrm{II})$ and $\mathrm{Pt}(\mathrm{IV})$ using activated carbon modified with 2,6-diaminopyridine. Microchim Acta 174:131-136

27. Vlasankova R, Otruba V, Bendl J, Fisera M, Kanicky V (1999) Preconcentration of platinum group metals on modified silica gel and their determination by inductively coupled plasma atomic emission spectrometry and inductively coupled plasma mass spectrometry in airborne particulates. Talanta 48:839-846

28. Müller M, Heumann KG (2000) Isotope dilution inductively coupled plasma quadrupole mass spectrometry in connection with a chromatographic separation for ultra trace determinations of platinum group elements ( $\mathrm{Pt}, \mathrm{Pd}, \mathrm{Ru}, \mathrm{Ir})$ in environmental samples. Fresenius J Anal Chem 368:109-115 